Research Paper

\title{
Cross-protection between experimental anti-leptospirosis bacterins
}

\author{
Cristina Corsi Dib ${ }^{1}$, Amane Paldês Gonçales ${ }^{2}$, Zenaide Maria de Morais ${ }^{2}$, \\ Gisele Oliveira de Souza ${ }^{2}$, Fabiana Miraglia ${ }^{2}$, Patricia Antonia Estima Abreu ${ }^{3}$, \\ Silvio Arruda Vasconcellos ${ }^{2}$ \\ ${ }^{1}$ Laboratório de Tuberculose, Centro de Pesquisa e Desenvolvimento de Sanidade Animal, \\ Instituto Biológico, São Paulo, SP, Brazil. \\ ${ }^{2}$ Laboratório de Zoonoses Bacterianas, Departamento de Medicina Veterinária Preventiva e Saúde \\ Animal, Faculdade de Medicina Veterinária e Zootecnia, Universidade de São Paulo, \\ São Paulo, SP, Brazil. \\ ${ }^{3}$ Laboratório de Bacteriologia, Instituto Butantan, São Paulo, SP, Brazil.
}

Submitted: June 20, 2013; Approved: March 14, 2014.

\begin{abstract}
We investigated the existence of cross-protection between two anti-leptospirosis monovalent experimental bacterins produced with two strains of Leptospira serogroup Pomona: Fromm strain of serovar Kennewicky, isolated from pigs in the United States, and strain GR6 of serovar Pomona isolated from pigs in Brazil. Both were added of aluminum hydroxide as an adjuvant. Experimental bacterins were tested with the hamster potency test in order to assess protection provided against the disease and against the establishment of kidney infection. Controls were polyvalent commercial vaccine produced with Leptospira strains isolated outside Brazil, which included a representative of Pomona serovar, or Sorensen solution added of aluminum hydroxide adjuvant. The challenge was performed with cross-strains of serogroup Pomona tested in accordance with international standards established for the potency test. After 21 days of the challenge, survivors were killed to evaluate the condition of Leptospira renal carrier. Experimental bacterins protected hamsters against homologous and heterologous strains, demonstrating the existence of cross-protection. The commercial vaccine protected the hamsters challenged with both strains, but there was a high proportion of animals diagnosed as renal carriers when the challenge was performed with strain GR6, isolated from pigs in Brazil.
\end{abstract}

Key words: Pomona, hamsters, bacterin, cross-protection.

\section{Introduction}

Leptospirosis is a zoonosis caused by pathogenic bacteria in the genus Leptospira, transmitted directly or indirectly to men (Ahmed et al., 2009). It is considered today an emerging infectious disease, and it is of worldwide importance (Ko et al., 2009), although it occurs more frequently in tropical and subtropical areas (Ahmed et al., 2009).

Pigs are important sources of Leptospira infection to men and other species of domestic animals (Vijayachari et al., 2008). In general, infected pigs may shed a large num- ber of Leptospira in the urine for long periods of time (Miraglia et al., 2008).

Clinical signs observed in pig herds infected by Leptospira mainly involve the reproductive system, such as miscarriage, neonatal mortality, premature birth, and stillbirths. Increase in birth interval and reduction in litter size are also important, as well as temporary infertility and permanent sterility in sows (Ramos et al., 2006).

Pigs are considered a maintenance host of serovar Pomona, with prolonged and abundant shedding in urine. In its clinical form, infection varies in different herds (Soto, 2007; Suepaul et al., 2010). Serological studies conducted

Send correspondence to C.C. Dib. Laboratório de Tuberculose, Centro de Pesquisa e Desenvolvimento de Sanidade Animal, Instituto Biológico, Av. Conselheiro Rodrigues Alves 1252, 04014-002 São Paulo, SP, Brazil. E-mail: criscdib@biologico.sp.gov.br. 
in Brazil have identified the predominance of reactions to serovar Pomona in pig herds of several Brazilian states (Favero et al., 2002; Gonçalves et al., 2011; Miraglia et al., 2008).

The best preventive measure against swine leptospirosis is vaccination with bacterins, which are suspensions of polyvalent whole, inactivated bacterial cells, produced with the most common serovars found in a region or country (Gonçales, 2007). However, these bacterins have to be formulated with the lesser number of serovars possible, with special emphasis in the most common ones found in a given region or country (Tabata et al., 2002).

Anti-leptospirosis bacterins produced with whole cells have been, in general, very efficient in the protection against lethal infection in immunized animals, although protection is limited in duration, and restricted to the serovar components and those that are antigenically related to them (Suepaul et al., 2010). However, when efficacy of a vaccine against leptospirosis is analyzed, protection against lethal infection (death) should be differentiated from protection against the carrier state (organ infection and urinary shedding), mainly in pigs, animals in which the state of asymptomatic carrier may persist for years, making them important sources of infection for other animals and men (Naranjo et al., 2008).

Nowadays, few studies have been carried out to demonstrate the existence of cross-protection between Leptospira serogroups. Naranjo et al. (2008) demonstrated, using the potency test, cross-protection between a trivalent vaccine with serovars Canicola, Icterohaemorrhagiae, and Pomona, and homologous strains and two heterologous strains belonging to serovar Ballum. Sonrier et al. (2000) analyzed protection conferred to gerbils immunized with the aqueous phase (containing LPS) and the extract of antigenic purified protein, and demonstrated that LPS was only able to protect the animals against the homologous challenge with strains Icterohaemorrhagiae 193 and Canicola (can V). On the other hand, antigenic proteins extracted from virulent Canicola protected immunized animals from the challenge with heterologous strains, showing that the three serogroups (Autumnalis, Icterohaemorrhagiae, and Canicola) of Leptospira interrogans have common antigens responsible for cross-protection and found in virulent and avirulent strains in amounts dependent on the virulence of the strain. Tabata et al. (2002) verified the existence of cross-protection using neutralizing antibodies of serovars Hardjo and Guaricura against serovars Hardjo, Wolffi and Guaricura. In this case, the growth inhibition test was employed in the evaluation of anti-leptospirosis bacterins produced with different serovars of Sejroe group.

There is a consensus on the fact that protection conferred by anti-leptospirosis bacterins is serovar-specific, limiting their efficiency. However, it is likely that there are differences in immunogenic power of different strains of a same serogroup or serovar, not only in relation to protection against the disease, but also in relation to the protection against the renal carrier status (Bey and Johnson, 1982). This aspect has great epidemiological importance due to the persistence and dissemination of the infection in herds (Faine, 1999). The present study was designed to investigate the existence of cross-protection between two strains of Leptospira interrogans that are pathogenic to hamsters, both belonging to serogroup Pomona.

\section{Materials and Methods}

Two experimental monovalent bacterins were produced: Strain GR6 of Leptospira serovar Pomona isolated from sows in a slaughterhouse in the state of São Paulo (Miraglia et al., 2008), and Fromm strain of serovar Kennewicki, isolated from pigs in the USA, supplied by Salsbury Laboratories. Bacterins were used in a potency test to assess cross-protection according to the CFR 113.101 (United States of America, 2006). A commercial polyvalent bacterin was also used in the comparison of the results.

Experimental bacterins were produced by means of the culture of samples obtained directly from a macerate of liver of hamsters that were experimentally infected and killed in the agonic phase of the infection. Culture medium used was modified liquid EMJH (Ellinghausen-McCullough-Johnson-Harris, base DIFCO-Detroit, USA), enriched with $15 \%$ of rabbit serum, $1 \%$ calcium chloride and magnesium chloride, $3 \% \mathrm{~L}$-asparagine, $1 \%$ sodium pyruvate, peptone, and meat extract (Alves et al., 1996).

Bacterial cells were counted in a Petroff Hausser chamber in dark field microscopy. Vaccine dose was adjusted to $10^{7}$ cells in $180 \mu \mathrm{L}$, in which $20 \mu \mathrm{L}$ ( $10 \%$ of the total volume of the dose) of the adjuvant aluminum hydroxide were added at the moment of bacterin administration. After the number of cells was determined, cultures were centrifuged three times at $12,800 \mathrm{~g}$ for $30 \mathrm{~min}$ at $4{ }^{\circ} \mathrm{C}$, and washed with Sorensen buffer solution. The final pellet was resuspended in the total volume calculated as a function of the number of doses and total number of cells in culture. The final product was inactivated in a water bath at $56{ }^{\circ} \mathrm{C}$ for $20 \mathrm{~min}$. After that, the bacterin was divided into smaller aliquots according to the need, and frozen at $-20^{\circ} \mathrm{C}$.

Young male hamsters (Mesocricetus auratus) weighting 60 to $100 \mathrm{~g}$ were used. They were divided in lots of ten animals each, kept in polypropylene boxes with bedding of wood shavings. Animals had free access to treated water from the public water system and commercial pelleted feed. The boxes with the animals were kept in the infection facility of the Departamento de Medicina Veterinária e Saúde Animal at Faculdade de Medicina Veterinária e Zootecnia of Universidade de São Paulo.

Animals vaccinated were divided in groups of ten, as follows: twenty animals vaccinated with bacterin GR6; twenty animals vaccinated with bacterin Fromm; twenty 
animals vaccinated with commercial bacterin; and twenty animals treated with sterile saline solution $0.85 \%$ added of the aluminum hydroxide adjuvant. All the groups were challenged with strain GR6 or Fromm (Table 1).

All animals vaccinated with GR6, Fromm, and commercial bacterins, and the negative control group received two doses of $0.20 \mathrm{~mL}$ of bacterin or sterile saline solution $0.85 \%$ added of aluminum hydroxide $10 \%$, according to the case, by subcutaneous route with a 15-day interval between the two doses. After 15 days of the second dose of the vaccine, all animals were challenged with $0.2 \mathrm{~mL}$ of live culture of strains GR6 or Pomona Fromm by intraperitoneal route. After the challenge, animals were observed for 21 consecutive days, and those that died of leptospirosis were counted. At the end of this period, animals that survived the challenge were killed in a $\mathrm{CO}_{2}$ chamber and necropsied to collect their kidneys for culture in Fletcher medium to assess control of Leptospira renal infection.

Titration of the challenging inoculums with the two strains of the Pomona serogroup was carried out using hamsters divided into groups of five animals per strain, and ten animals in the dilutions of strains Fromm and GR6 chosen for the challenge, respectively, $10^{-6}$ and $10^{-2}$.

Animals inoculated with strain GR6 were divided in seven groups according to the challenge dilution used, which ranged from $10^{-1}$ to $10^{-7}$, in a geometric scale with ratio 10. Animals inoculated with Fromm strain received one dose between dilutions $10^{-5}$ and $10^{-10}$.

Challenge doses were $0.2 \mathrm{~mL} /$ hamster, by intraperitoneal route. Animals were observed every day for 21 days, and Reed and Muench (1938) method was used to calculate the lethal dose $\left(\mathrm{LD}_{50}\right)$.

Twenty one days post-infection (d.p.i) by Leptospira, surviving hamsters were killed in a $\mathrm{CO}_{2}$ chamber. Animals were necropsied and their kidneys were aseptically collected and ground, and then diluted in Sorensen buffer solu-
Table 1 - Hamsters submitted to the potency test of anti-leptospirosis bacterin according to the type of immunogen, the Leptospira strain used in the challenge and the identification number of the experimental group.

\begin{tabular}{lcc}
\hline Group & Type of immunogen & Challenge strain \\
\hline 1 & Sterile saline solution $0.85 \%$ and aluminum & GR6 \\
hydroxide $10 \%$ & \\
2 & Sterile saline solution $0.85 \%$ and aluminum & Fromm \\
hydroxide $10 \%$ & \\
3 & Bacterin GR6 & GR6 \\
4 & Bacterin GR6 & Fromm \\
5 & Bacterin Fromm & GR6 \\
6 & Bacterin Fromm & Fromm \\
7 & Commercial bacterin & GR6 \\
8 & Commercial bacterin & Fromm \\
\hline
\end{tabular}

tion in tenfold serial dilutions $\left(10^{-1}\right.$ to $\left.10^{-3}\right)$. For each dilution, $100 \mu \mathrm{L}$ were cultured in two tubes containing semi-solid Fletcher medium, and incubated at $28-30{ }^{\circ} \mathrm{C}$ for six weeks. Cultures were observed weekly to assess Leptospira ring of growth in the medium, confirmed by the presence of Leptospira in dark field microscopy.

The study was analyzed and approved by the Bioethics Committee at Faculdade de Medicina Veterinária e Zootecnia of Universidade de São Paulo, protocol number $1430 / 2008$

\section{Results}

Results presented in Tables 2 and 3 enabled the calculation of $\mathrm{LD}_{50}$ by the Leptospira strain used in the challenge, respectively $10^{-5.3033}$ for strain GR6, and $10^{-7.6896}$ for Fromm strain, as well as the $\mathrm{LD}_{50}$ effectively used, respectively, 2010 for strain GR6 and 48.9 for Fromm strain. As the CFR 113.101 (United States of America, 2006) determines that $\mathrm{LD}_{50}$ should be between 10 and 10,000 , it may

Table 2 - Number of hamsters challenged with strain GR6 of Leptospira interrogans serovar Pomona at the end of the 21-day observation period according to the dilution of the infective inoculum, the condition of the animals and the parameters necessary to calculate $\mathrm{LD}_{50}$ according to the Reed and Muench method (12).

\begin{tabular}{|c|c|c|c|c|c|}
\hline D & $\mathrm{S}$ & M & $\begin{array}{l}\text { Accumulated frequency } \\
\qquad \mathrm{S}(\mathrm{b})\end{array}$ & $\begin{array}{c}\mathrm{c} /(\mathrm{b}+\mathrm{c})(\text { Cumulative } \% \text { of deaths }) \\
\mathrm{M}(\mathrm{c})\end{array}$ & Total $(b+c)$ \\
\hline $10^{-1}$ & 1 & 4 & 1 & 28 & 29 \\
\hline $10^{-2}$ & 3 & 7 & 4 & 24 & 28 \\
\hline $10^{-3}$ & 1 & 4 & 5 & 17 & 22 \\
\hline $10^{-4}$ & 2 & 3 & 7 & 13 & 20 \\
\hline $10^{-5}$ & 2 & 3 & 9 & 10 & 19 \\
\hline $10^{-6}$ & 0 & 5 & 9 & 7 & 16 \\
\hline $10^{-7}$ & 3 & 2 & 12 & 2 & 14 \\
\hline
\end{tabular}

D: Dilution of the infective challenge inoculum with strain GR6 of serovar Pomona.

S: Number of animals that survived the Leptospira infection.

M: Number of deaths caused by leptospirosis.

$\mathrm{LD}_{50}=10^{-5.3033}$. 
Table 3 - Number of hamsters challenged with strain Fromm of Leptospira interrogans serovar Pomona at the end of the 21-day observation period according to the dilution of the infective inoculum, the condition of the animals, and the parameters necessary to calculate $\mathrm{LD}_{50}$ according to the Reed and Muench method (12).

\begin{tabular}{|c|c|c|c|c|c|}
\hline $\mathrm{D}$ & S & M & $\begin{array}{l}\text { Accumulated frequency } \\
\qquad \mathrm{S}(\mathrm{b})\end{array}$ & $\begin{array}{c}\mathrm{c} /(\mathrm{b}+\mathrm{c})(\text { cummulative } \% \text { of deaths }) \\
\mathrm{M}(\mathrm{c})\end{array}$ & Total $(b+c)$ \\
\hline $10^{-5}$ & 2 & 3 & 2 & 19 & 21 \\
\hline $10^{-6}$ & 3 & 7 & 5 & 16 & 21 \\
\hline $10^{-7}$ & 1 & 4 & 6 & 9 & 15 \\
\hline $10^{-8}$ & 0 & 0 & 6 & 5 & 11 \\
\hline $10^{-9}$ & 5 & 5 & 11 & 0 & 11 \\
\hline
\end{tabular}

D: Dilution of the infective challenge inoculum with strain Fromm of serovar Pomona.

S: Number of animals that survived the Leptospira infection.

M: Number of deaths caused by leptospirosis.

$\mathrm{LD}_{50}=10^{-7.6896}$.

Table 4 - Proportion of hamsters that survived the challenge according to the type of immunogen used and the strain of the Pomona serogroup used. São Paulo, 2012.

\begin{tabular}{lc}
\hline Type of immunogen & $\begin{array}{c}\text { Challenge strain of serovar Pomona } \\
\text { GR6 }\end{array}$ \\
\hline $\begin{array}{l}\text { Sterile saline solution } 0.85 \% \\
\text { and aluminum hydroxide }\end{array}$ & $5 / 10$ \\
Bacterin GR6 & $10 / 10$ \\
Bacterin Fromm & $10 / 10$ \\
Commercial bacterin & $8 / 10$ \\
\hline
\end{tabular}

*Number of survivors/number of challenged animals.

be considered that for the two strains used, $\mathrm{LD}_{50}$ effectively used were inside the accepted range.

Control animals vaccinated with sterile saline solution $0.85 \%$ added of aluminum hydroxide as the adjuvant and challenged with strain GR6 showed a rate of survival of five animals from the ten challenged. This result is greater than the maximum established in the CFR 113.101 (United States of America, 2006) (2/10). However, the five survivors showed kidney cultures positive for Leptospira. In the control group, animals challenged with Fromm strain showed only one survivor in ten animals, a result that is in agreement with the CFR 113.101 guidelines (United States of America, 2006) (Table 4).

Animals immunized with the experimental polyvalent bacterin were protected against the two strains of Leptospira used in the challenge, with the number of survivors inside the range determined by the CFR 113.101 (United States of America, 2006) for the vaccine to be approved (8/10).

Table 5 presents the results of the cultures in Fletcher medium used to assess the presence of Leptospira in the kidneys of hamsters vaccinated and surviving the challenge with GR6 and Fromm strains. From ten animals vaccinated with bacterin GR6 that survived the challenge, only one was confirmed as a renal carrier of Leptospira. All animals
Table 5 - Proportion of hamsters vaccinated and that survived the challenge with strains GR6 e Fromm of Leptospira interrogans serogroup Pomona characterized as renal carriers of Leptospira 21 post-infection, according to the type of treatment used.

\begin{tabular}{lcc}
\hline Type of treatment & GR6 & Fromm \\
\hline Sterile saline solution $0.85 \%$ and aluminum hydroxide & $5 / 5$ & $0 / 1$ \\
Bacterin GR6 & $1 / 10$ & $0 / 10$ \\
Bacterin Fromm & $0 / 10$ & $0 / 10$ \\
Commercial bacterin & $7 / 8$ & $0 / 9$ \\
\hline
\end{tabular}

vaccinated with bacterin Fromm presented kidney culture for negative for Leptospira. On the other hand, the polyvalent commercial bacterin protected against renal colonization only in the group of animals challenged with Fromm strain. In the group of animals challenged with strain GR6, seven of eight survivors showed kidney culture positive for Leptospira.

\section{Discussion}

All animals immunized with the experimental monovalent bacterins produced with Fromm and GR6 strains survived the challenge with the two homologous or heterologous strains, confirming the occurrence of cross-protection between these two members of the Pomona serogroup.

Studies involving the evaluation of anti-leptospirosis bacterin recommend Leptospira counts between $10^{6}$ (Zeigler et al., 1978) and $10^{9}$ cells per $\mathrm{mL}$ of medium (Zeigler et al., 1976; González et al., 2005). Due to these previous studies with experimental bacterins, it was decided on a concentration of $10^{7}$ cells per dose of $200 \mu \mathrm{L}$ of bacterin, with $180 \mu \mathrm{L}$ of bacterin and $20 \mu \mathrm{L}$ of aluminum hydroxide as the adjuvant.

Results presented in Table 3 comply with the protocol determined by the CFR 113.101 (United States of America, 2006), which considers the vaccine approved when the rate of deaths by leptospirosis with the challenge inoculum con- 
taining between 10 and $10,000 \mathrm{LD}_{50}$ is equal or greater than $8 / 10$ in the non-vaccinated control group, and not greater than $2 / 10$ or $5 / 20$ in the vaccinated group. It is possible to observe that, although the group of vaccinated animals presented a result that is considered satisfactory by these international guidelines, in the animals vaccinated with both experimental vaccines, and in control animals vaccinated with sterile saline solution and aluminum hydroxide that were challenged with strain Pomona GR6, mortality was only five animals in ten inoculated, a result that is not in compliance with the criteria determined by the potency test protocol. In this protocol, mortality of the control animals should be less than eight in ten animals. However, all five survivors showed kidney cultures positive for Leptospira, confirming the exposure to the agent and showing that, in this case, strain GR6 was less pathogenic to hamsters than Fromm strain. In fact, virulence of Fromm strain has been kept by successive passages in hamsters, preserving its pathogenicity for these animals (Tabata et al., 2002).

Strain GR6 was isolated by Miraglia et al. (2008) and was kept in semi-solid Fletcher medium with six-month replications. When this study was carried out, strain GR6 was submitted to successive "blind" passages in hamsters in order to recover its virulence and pathogenicity, which could have been attenuated in the synthetic media (Reed et al., 2000).

In animals vaccinated and challenged with Fromm strain, no animal was characterized as a renal carrier. On the contrary, animals challenged with strain GR6 showed a large proportion of renal carriers among animals vaccinated with the polyvalent commercial bacterin (7/8). This assessment indicates that although the two strains that were used belong to the same serogroup, protection conferred by the commercial bacterin produced with Leptospira strains isolated outside of Brazil was not enough to protect against infection and colonization of the kidneys in animals challenged with a strain of Leptospira of the same serogroup that occur in pig herds in Brazil.

Although PCR is considered more sensitive, culture of Leptospira is often used for evaluation of carrier status in hamsters kidney in potency tests of bacterins. The results of the isolation of Leptospira in the kidneys of hamsters challenged with strain GR6 were satisfactory and consistent with the virulence characteristics and maintenance of the two strains in the laboratory.

In the present study, although the group of non-vaccinated control animals challenged with strain GR6, the minimum proportion of animals killed by leptospirosis (5/10) was lower than that required by the CFR 113.101 (United States of America, 2006) (8/10), the $\mathrm{LD}_{50}$ effectively employed (2010) was inside the accepted range (10 to 10000), and all survivors to the challenge presented renal cultures positive for Leptospira. Therefore, the occurrence of cross-protection between the two strains may be considered, mainly in animals immunized with monovalent ex- perimental bacterins. It was also demonstrated that experimental bacterins presented results proportionally greater when challenged with homologous and heterologous strains when compared with the commercial polyvalent vaccine, preventing the colonization of the kidneys by Leptospira in almost all vaccinated hamsters, compared with the high proportion of Leptospira isolation in the kidneys when the commercial bacterin was used.

\section{Conclusions}

Experimental bacterins produced with Fromm strain of serovar Kennewicki and Pomona GR6, both belonging to the Pomona serogroup of L. interrogans protected the hamsters against the homologous and heterologous challenge, demonstrating cross-protection. The high proportion of hamsters vaccinated with the commercial bacterin and characterized as renal carriers of strain GR6 confirms the need to develop commercial bacterins with Leptospira isolates that occur in Brazil.

\section{References}

Ahmed A, Engelberts MFM, Boer KR, Ahmed N, Hartskeerl RA (2009) Development and validation of real-time PCR for detection of pathogenic Leptospira species in clinical materials. PLoS ONE 4:e7093.

Alves CJ, Vasconcellos AS, Camargo CRA, Morais ZM (1996) Influência de fatores ambientais na proporção de caprinos soro-reagentes para a leptospirose em cinco centros de criação do Estado da Paraíba. Arq Inst Biol 63:11-18.

Bey RF, Johnson RC (1982) Immunogenicity and humoral and cell-mediated immune response to leptospiral whole cell, outer envelope, and protoplasmic cylinder vaccines in hamsters and dogs. Am J Vet Res 43:835-840.

Faine, S, Adler B, Bolin, C, Perolat P (1999). Leptospira and Leptospirosis. 2 ed. Medisci, Melbourne, Australia.

Favero ACM, Pinheiro SR, Vasconcellos SA, Morais ZM, Ferreira F, Ferreira-Neto JS (2002) Sorovares de leptospiras predominantes em exames sorológicos de bubalinos, ovinos, caprinos e equinos, suínos e cães de diversos estados brasileiros. Ciência Rural 32:613-619.

Gonçales AP (2007) Avaliação de vacinas anti-leptospirose. Relação entre o teste de inibição de crescimento in vitro e teste de desafio em hamster. M.Sc. Dissertation, Faculdade de Medicina Veterinária e Zootecnia, São Paulo, 96 p.

Gonçalves LMF, Costa FAL (2011) Leptospirose em suínos no Brasil. Rev Pat Trop 40:1-14.

González A, Rodríguez Y, Batista N, Valdés Y, Núñez JF, Mirabal M, González M (2005) Inmunogenicidad y capacidad protectora en hamsters de vacunas antileptospirósicas monovalentes de células enteras del serogrupo Ballum. Rev Arg Microbiol 37:169-175.

Ko AI, Goarant C, Picardeau M (2009) Leptospira: the dawn of the molecular genetics era for an emerging zoonotic pathogen. Nat Rev Microbiol 7: 736-747.

Miraglia F, Moreno, AM, Gomes CR, Paixão R, Liuson E, Morais ZM, Maiorka P, Seixas FK, Dellagostin OA, Vasconcellos SA (2008) Isolation and characterization of Leptospira 
interrogans from pigs slaughtered in São Paulo State, Brasil. Braz J Microbiol 39:501-507.

Naranjo M, Batista N, Valdés Y, González M, Infante J, Sierra G (2008) vax-SPIRAL ${ }^{\circledR}$, vacuna trivalente (Canicola-Icterohaemorrhagiae-Pomona). Capacidad protectogénica cruzada frente al reto com L. Ballum de alta patogenicidad em el modelo Hámster Sirio Dorado. Vaccimonitor 17:14-19.

Ramos AC, Souza GN, Lilenbaum W (2006) Influence of leptospirosis on reproductive performance of sows in Brazil. Theriogenology 66:1021-1025.

Reed LJ, Muench H (1938) A simple method of estimating fifty per cent endpoints. Am J Hygiene 27:493-497.

Reed NE, Varney WC, Goddard RD, Wyeth PJ (2000) The maintenance of challenge strains used in the potency test for canine leptospira vaccines. Biologicals 28:25-28.

Sonrier C, Branger C, Michel V, Ruvoën-Clouet N, Ganière JP, André-Fontaine G (2000) Evidence of cross-protection within Leptospira interrogans in an experimental model. Vaccine 19:86-94.

Soto FRM, Vasconcellos SA, Pinheiro SR, Bernarsi F, Camargo SR (2007) Leptospirose suína. Arq Inst Biol 74:379-395.

Suepaul SM, Carrington CV, Campbell M, Borde G, Adesiyun AA (2010) Study on the efficacy of Leptospira vaccines developed from serovars isolated from Trinidad and compari- son with commercial vaccines using a hamster model. Vaccine 28:5421-5426.

Tabata, R, Scanavini Neto H, Zuanaze MAF, Oliveira EMD, Dias RA, Morais ZM, Ito FH, Vasconcellos SA (2002) Cross neutralizing antibodies in hamsters vaccinated with leptospiral bacterins produced with three serovars of serogroup Sejroe. Braz J Microbiol 33:265-268.

Vijayachari P, Sugunan AP, Shriram AN (2008) Leptospirosis: an emerging global public health problem. J Biosci 33: 557-569.

United States of America. Department of Agriculture. (2006) 113.10 Leptospira Pomona bacterin. In: Code Federal Regulations. Animals and products, Washington Government Printing Office via GPO Acess, pt 113, sec. E., p 685.

Zeigler JA, Jones RH, Kubica K (1976) Immunization against leptospirosis: vaccine trials with heat-killed whole cell and outer envelope antigens in hamsters. Bull Pan Am Health Organ 12:126-130.

Zeigler JA, Kubica KM, Jones RH (1978) Immunization against leptospirosis: continued vaccine trials in hamsters using strains isolated from Barbados. Bull Pan Am Organ $12: 130-133$

All the content of the journal, except where otherwise noted, is licensed under a Creative Commons License CC BY-NC. 